TITLE:

OCCURRENCE OF A NEW

PEDUNCULATE CIRRIPED ON A

SMALL SPANISH LOBSTER

SCYLLARUS BICUSPIDATUS (DE

MAN) FROM KAMAE BAY,

NORTHEASTERN KYUSYU

\author{
$\operatorname{AUTHOR}(\mathrm{S})$ : \\ Utinomi, Huzio
}

CITATION:

Utinomi, Huzio. OCCURRENCE OF A NEW PEDUNCULATE CIRRIPED ON A SMALL SPANISH LOBSTER SCYLLARUS BICUSPIDATUS (DE MAN) FROM KAMAE BAY, NORTHEASTERN

KYUSYU. PUBLICATIONS OF THE SETO MARINE BIOLOGICAL LABORATORY 1967, 15(2):

$117-120$

ISSUE DATE:

1967-09-11

URL:

http://hdl.handle.net/2433/175462

RIGHT: 


\title{
OCCURRENCE OF A NEW PEDUNCULATE CIRRIPED ON A SMALL SPANISH LOBSTER SCYLLARUS BICUSPIDATUS (DE MAN) FROM KAMAE BAY, NORTHEASTERN KYUSYU*
}

\author{
HuZIO UTINOMI
}

Seto Marine Biological Laboratory, Sirahama

With 2 Text-figures

During a biological survey of the reef coral area in Kamae Bay, a small inlet located on the coast of Oita Prefecture, northeastern Kyusyu, carried out by the co-operation of staffs of the Seto Marine Biological Laboratory, Kyoto University and the Oita Marine Palace, Oita City under the leadership of Dr. Denzaburo Mryadi, former Director of the Seto Laboratory, on July 17-21th, 1965, Dr. Takasi ToкIоkA of our Laboratory found two small pedunculate cirripeds attached on a small Spanish lobster Scyllarus bicuspidatus (DE MAN) caught at low tide. After he returned home, he handed over this cirriped to me for identification.

Subsequent examination revealed that this interesting cirriped represents an undescribed species of the genus Paralepas Pilsbry, 1907. So the description of this new species follows.

\section{Paralepas scyllarusi UTINomi, n. sp.}

(Himesemiebi-hadakaebosi, nom. nov.)

Types: Holotype (SMBL Type 201) and paratype (SMBL Type 201a) deposited in the museum of the Seto Marine Biological Laboratory.

Type locality: Kamae Bay, southeast coast of Oita Prefecture, eastern Kyusyu. Collected by Dr. T. TokıокA at low tide. 20-VII-1965.

Habitat: Attached to the base of uropod of a small Spanish lobster Scyllarus bicuspidatus (DE MAN), about $18 \mathrm{~mm}$ in carapace length.

Colour in life: Whitish, with a brownish red tinge around the carinal crest.

Size: Holotype $9 \mathrm{~mm}$ long, $3 \mathrm{~mm}$ wide. Paratype $5 \mathrm{~mm}$ long, $2 \mathrm{~mm}$ wide.

Description of the holotype: The capitulum is elongate oval in outline, laterally compressed, thin, soft, somewhat gelatinous and with a slight translucent carinal crest running from the apex to the bottom of capitulum. The integument is quite smooth

* Biological studies of the reef coral area of Kamae Bay, No. 1 and Contributions from the Seto Marine Biological Laboratory, No. 466, also Contributions from the Oita Ecological Aquarium, No. 13.

Pụbl. Seto Mar. Bịol. Lab., XV (2), 117-120, 196̣. (Article 6) 
and lacks any trace of the scuta. The orifice is slit-like, not protuberant, with puckered lips, occupying less than an half as long as the capitulum. The occludent margin below the orifice is evenly convex and gradually sloping downwards, where the limit between the capitulum and peduncle cannot be defined distinctly. The peduncle is tapering to the bottom of attchment and approximately a little longer than the capitulum. It is quite cylindrical but not annulated.

The entrance to the mantle cavity near the orifice is somewhat tubular and encircled by fine fibres. A number of nauplii before hatching were contained freely within the broad mantle cavity.

The cirri and their setation are weakly developed for the genus, although it is natural for the small size of the animal. All the cirri are extremely short and slightly curled, though their protopodite (especially the lower segment) is comparatively rather long, occupying about one-third of the total length. The number of segments in their rami and the caudal appendage is as follows:

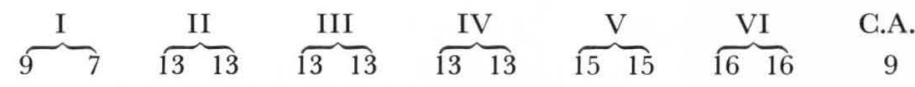

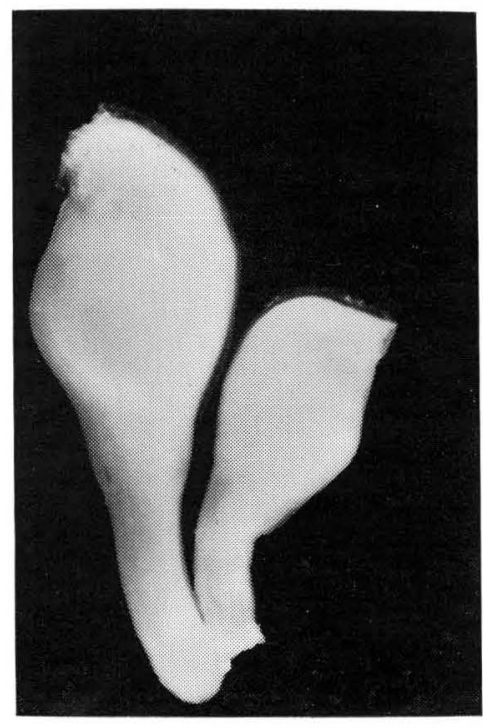

$\boldsymbol{a}$
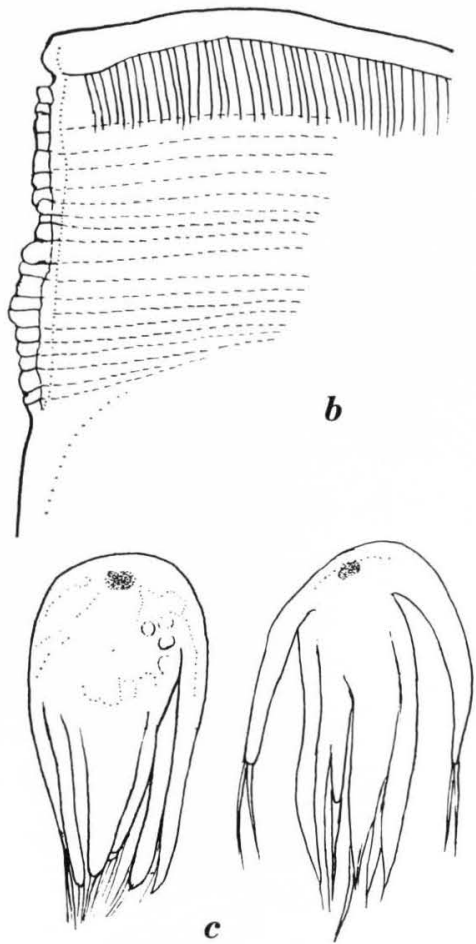

Fig. 1. Paralepas scyllarusi Utinomi, n. sp. a, Holotype (left) and paratype (right), attached together at base, the carinal crest on the dorsum of capitulum being translucently reflected. Photo: Ch. Araga. $\times 6.6$. $b$, Puckered lip and entrance to the mantle cavity. $\quad \times 30 . \quad c$, Nauplii before hatching contained in the mantle cavity. $\times 150$. 
Cirrus I placed near the mouth has a thin, horn-like filamentary appendage at the posterior base of the lower segment, as usual, and their rami are slightly unequal in length and setation. In the remaining cirri, both the rami are subequal in length and setation; each segment in the intermediate part is elongate quadrangular and not protuberant along the anterior border, although the lowest segment is considerably elongate or made up of fused ones. As mentioned above, the setation is extremely weak. Namely, the anterior border of each segment of the cirri supports about 4 pairs of slender simple setae on its distal half rather sparsely tufted, and the posterior distal angle bears only a tuft of 2-3 slenderer approximate setae, not forming a semicircle row. Accordingly, the setation mentioned above seems to present a unique bridge between the characteristic setation of both the genera (formerly subgenera) Heteralepas and Paralepas.

The caudal appendage is a little longer than the protopodite of the last cirri and bears a few hairlike setae in each segment distally.

The penis is broad, tapering, about half as long as the last cirri, coarsely annulated and furnished with many minute rivet-like structures like those of $P$. palinuri urae Newman (1960, fig. 6G) and $P$. distincta Utinomi (1949, fig. 2D), both occurring

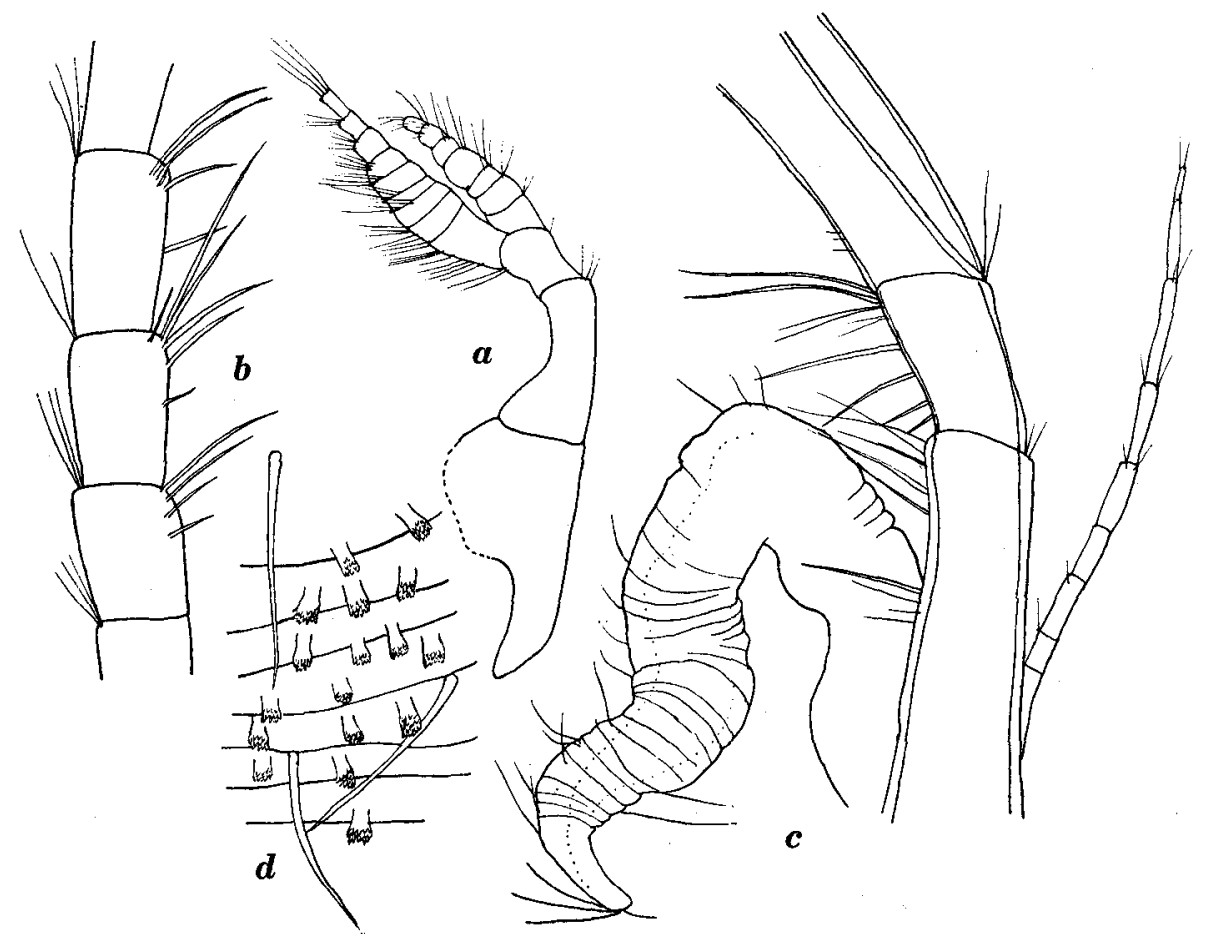

Fig. 2. Paralepas scyllarusi Utinomi, n. sp. a, Cirrus I with a filamentary appendage at base. $\times 30$. b, Intermediate segments of cirrus IV. $\times 96$. $c$, Basal part of cirrus VI with caudal appendage and penis. $\times 53 . d$, Surface of penis much magnified, showing the arrangement of rivet-like structures and setae in rings. $\times 150$. 
on Panulirus, as well as those of P. lithotryae (HoEk, 1907, pl. IX, figs. 8-8') occurring on the valves of Lithotrya; the setae on the penis are generally long and rather sparse, all directing downwards like the rivet-like structures.

The mouthparts are typical of the genus Paralepas. Unfortunately, however, I could not illustrate herein, as they were missing in preparation.

Affinity: In external appearance the form here described resembles most closely Paralepas intermedia (Hokк, 1907, p. 37, pl. IV, figs. 13-16) of the hitherto known 17 species or forms, recently reviewed by Newman (1960, pp. 108-110; synonyms included), but apparently seems to be different in having the charaeteristic weak setation in the posterior cirri and in the armature of rivet-like structures on the penis. In $P$. intermedia, on the other hand, each segment of the cirri bears 2 claw-like setae at the posterior distal angle and a semicircle of longer setae at the anterior distal angle, although not figured by HoEk, and the occurrence of rivet-like structures on the penis is not mentioned, although he confirmed the rivet-like armatures in the related species $P$. lithoiryae, simultaneously described. Furthermore, the disparity of habitat may prove the separation of both forms, since $P$. intermedia was originally found on stones and shells dredged at a depth of $90 \mathrm{~m}$ near the Kei Islands, Indonesia and later rediscovered on spines of a Histocidaris dredged at 200-250 fms in the Tasman Sea (Broci, 1922, p. 281). The other related species P. lithoiryae (НоEк) which has been found attached to the valves of intertidal Litholrya is also small with an obscure boundary between the capitulum and peduncle, but the capitulum is more robust and globular and the peduncle $i ;$ very short and indistinctly ringed (HoEk, 1907, p. 39, pl. IX, figs. 5-8'; Nilsson-Cantell, 1934, p. 56, fig. 2).

\section{LITERATURE CITED}

Broch, Hjalmar 1922. Papers from Dr. Th. Mortensen's Pacific Expedition 1914-16. X. Studies on Pacific Cirripeds. Vidensk. Medd. fra Dansk naturh. Foren., vol. 73, pp. 215-358.

Hozk, P.P.C. 1907. The Cirripedia of the Siboga Expedition. A. Cirripedia Pedunculata. SibogaExpeditie, monogr. 31a, pp. 1-127, pls. I-X.

Newman, W.A. 1960. Five pedunculate cirripeds from the western Pacific, including two new forms. Crustaceana, vol. 1, pt. 2, pp. 101-116.

Nilsson-Cantell, G.A. 1934. Indo-Malayan cirripeds in the Raffles Museum, Singapore. Bull. Raffles Mus., no. 9, pp. 42-73, pl. V.

Utinom, H. 1949. Studies on the Cirripedian fauna of Japan. VI. Cirripeds from Kyusyu and Ryukyu Islands. Publ. Seto Mar. Biol. Lab., vol. 1, no. 2, pp. 19-37. 